\title{
MUSTAHIQ ZAKAT PADI MENURUT PERSEPSI MASYARAKAT TOBING JULU KEC. HURISTAK KAB. PADANG LAWAS
}

\author{
Risalan Basri Harahap \\ Fakultas Syariah Dan Ilmu Hukum IAIN Padangsidimpuan \\ risalanbasriharahap@iain-padangsidimpuan.ac.id
}

\begin{abstract}
In carrying out the payment of rice farming zakat in Huristak District, Padang Lawas District, the farmers in giving their zakat determines the person who becomes mustahiq, usually is the fisabilillah category because that is what is usually there especially the amil that is officially determined does not yet exist. From the tradition that passed in the midst of the community where the farmers after giving their zakat to the mustahiq, then the mustahiq took their share $1 / 8$ of the zakat they received, the rest handed back to muzakki to be used according to their needs. And usually if mustahiq does not give part of it back to the muzakkin, then mustahiq will become a chatter of people in the community and the simuzakki will not want to give zakat to him at the next harvest. The reason for mustahiq returning his zakat right to muzakki after taking it partially in the district Huristak Kab Padang Lawas. From each of the rice farmers who have the obligation to pay their income zakat (enough Nisab). mustahiq said that the zakat is only $1 / 8$, while the rest is the rights of others who are stipulated by Allah in the Qur'an, because mustahiq cannot give to mustahiq which is partly returned to the muzakki so that it can be given to others.
\end{abstract}

Keywords: Perception, Mustahiq, Agricultural Zakat

\begin{abstract}
Abstrak
Dalam pelaksanaan pembayaran zakat pertanian padi di Kec Huristak Kab Padang Lawas para petani dalam memberikan zakatnya menentukan sendiri orang yang menjadi mustahiqnya, biasanya adalah kategori fisabilillah karena memang itulah yang biasa disana apalagi amil yang ditentukan secara resmi belum ada. Dari tradisi yang berlalu ditengah masyarakat tersebut dimana para petani setelah memberikan zakatnya kepada yang mustahiq, kemudian mustahiq tersebut mengambil bagiannya $1 / 8$ dari zakat yang diterimanya selebihnya menyerahkan kembali kepada muzakki untuk dapat dipergunakan sesuai dengan kebutuhannya. Dan biasanya kalau mustahiq tidak menyerahkan sebagian kembali kepada si muzakkinya maka mustahiq tersebut akan menjadi ocehan orang dimasyarakat dan simuzakki tersebut tidak akan mau memberikan zakat kepadanya pada saat panen selanjutnya. Alasan mustahiq mengembalikan hak zakatnya kepada muzakki setelah mengambilnya sebagian di Kec. Huristak Kab Padang Lawas. Dari masing-masing para petani padi yang sudah berkewajiban membayar zakat penghasilannya (cukup nisab). mustahiq mengatakan zakat itu haknya hanya $1 / 8$ saja, sedangkan selebihnya adalah menjadi hak orang lain yang ditetapkan Allah dalam Alqur'an, oleh
\end{abstract}


344 | TAZKIR: Jurnal Penelitian Ilmu-ilmu Sosial dan Keislaman

Vol. 04 No. 2 Desember 2018

karena mustahiq tidak bisa memberikan kepada mustahiq yang sebagian lagi maka zakat dikembalikan kepada muzakki agar dapat diberikan kepada yang lain.

Kata Kunci: Mustahiq, Zakat, Persepsi Masyarakat.

\section{PENDAHULUAN}

Islam merupakan agama universal yang mengatur setiap aktifitas manusia salah satu di antaranya adalah zakat. Zakat merupakan kewajiban setiap muslim yang harus ditunaikan apa bila syarat-syaratnya sudah terpenuhi. Zakat juga mempunyai peran aktif dalam system perekonomian. Karena zakat merupakan sesuatu yang mendorong kehidupan ekonomi hingga tercipta padanya pengaruh tertentu. Misalnya, meringankan penderitaan hidup dari golongan yang tidak mampu atau menolong kepentingan masyarakat dan negara. Kewajiban zakat ini telah di tetapkan Allah SWT dalam Q. S. AlBaqarah: 43:

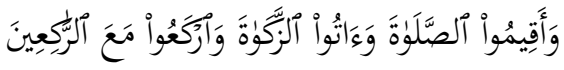

Artinya: Dan dirikanlah shalat, tunaikanlah zakat dan ruku'lah beserta orang orang yang ruku'

Secara ekonomi zakat merupakan pemindahan harta kekayaan dari golongan kaya kepada golongan tidak punya. Ajaran Islam menjadikan yang mempunyai aspek sosial sebagai landasan membangun sistem yang mewujutkan kesejahteraan dunia akhirat. Dengan mengintek rasikannya dalam ibadah berarti memberikan peran penting pada keyakinan keimanan yang mengendalikan seseorang dalam hidupnya. Demikianlah fungsi sesungguhnya dari ibadah yang dikenal dengan nama zakat. Dalam kelanjutannya pengorganisasi dan kekuasaan yang mengatur dan mengayomi masyarakat juga diikutsertakan, yaitu dengan adanya Amil Imam atau Khalifah yang aktif dalam menjalankan dan mengatur pelaksaanaan zakat, zakat memang bukanlah satu-satunya gambaran dari sistem yang ditampilkan dari ajaran Islam dan mewujudkan kesejahteraan umum bagi masyarakat, Namun harus dilalui bahwa zakat sangat penting kedudukannya karena ia merupakan senter dari system tersebut.

Menurut syar'iat, zakat berarti hak yang wajib dikeluarkan dari harta, Dengan maksud mensucikan harta, orang yang mangeluarkannya dan akan menumbuhkan pahala seseorang dikatakan berhati suci dan mulia apa bila ia tidak kikir dan tidak mencintai harta untuk kepentingan diri sendiri, Orang yang 
membelanjakan hartanya untuk orang lain akan memperoleh kesucian dan kemuliaan.

Menurut As-Sayyid Sabiq, ada lima kategori harta yang wajib dizakati, yaitu emas, perak, perdagangan, barangtemuan (harta karun), pertanian dan peternakan.

Dari kelima zakat maal tersebut yang menjadi fokus perhatian dari penelitian ini adalah tentang zakat darihasil pertanian, khusunya zakat pada tanaman padi. Zakat hasil pertanian berbeda dengan zakat kekayaan-kekayaan yang lain, seperti ternak, uang, dan barang-barang dagang. Perbedaan itu adalahbahwa zakatnya tidak bergantung dari berlalunya tempo satu tahun (haul), oleh karena benda yang dizakatkan itu merupakan produksi atau hasil yang diberikan oleh tanah, artinya bila produksi ini diperoleh, yang merupakan wajibnya zakat. Dalam istilah modern sekarang, zakat itu merupakan pajak produksi yang diperoleh dari eksploitasi tanah.

Yusuf Qardhawi menguraikan syarat-syarat harta yang wajib dizakati sebagai berikut: ${ }^{1}$

1. Milik Penuh

Pemilikan berarti "menguasai dan dapat dipergunakan" sesuai dengan pengertian yang terdapat di dalam kamus. Maksudnya milik penuh adalah bahwa kekayaan itu harus berada di bawah kontrol dan di dalam kekuasaanya atau seperti yang dinyatakan sebagian ahli fiqih bahwa kekayaan itu harus berada ditangannya tidak tersangkut di dalamnya hak orang lain dapat dipergunakan dan faedahnya di nikmatinya.

2. Berkembang.

Ketentuan tentang kekayaan yang wajib dizakatkan adalah bahwa kekayaan itu berkembang dengan sengaja atau mempunyai potensi untuk berkembang. Menurut ahli-ahli fiqih, "berkembang" menurut terminologi berarti "bertambah". Pengertian ini terbagi menjadi dua, yakni bertambah secara konkrit. Secara, konkrit berarti bertambah akibat pembiakan dan perdagangan dan sejenisnya, yang tidak konkrit adalah kekayaan itu berpotensi berkembang baik berada ditangannya, maupun ditangan orang lain atas namanya.

1 Yusuf Qardawi. Hukum Zakat: Studi Komperati Mengenai Status dan Filsafat Zakat Berdasarkan qur'an hadits, (Bogor : Pustaka Litera Antar Nusa, 2002), hlm. 310 
346 | TAZKIR: Jurnal Penelitian Ilmu-ilmu Sosial dan Keislaman

Vol. 04 No. 2 Desember 2018

3. Cukup Mencapai Nisab.

Islam tidak mewajibkan zakat atas seberapa saja besar kekayaan yang berkembang sekalipun keci sekali, tetapi memberi ketentuan sendiri yaitu sejumlah tersedia yang dalam ilmu fikih disebut nisab. Dengan kata lain nisab ialah jumlah minimal yang menyebabkan harta terkena, kewajiban zakat.

4. Lebih dari Kebutuhan Biasa

Diantara ulama-ulam fikih ada yang menambahkan ketentuan nisab kekayaan yang berkembang itu dengan lebihnya kekayaan itu dari kebutuhan biasa pemiliknya, misalnya ulama-ulama Hanafi dalam kebanyakan kitab mereka. Tetapi ada ulama-ulama yang tidak memasukkan ketentuan itu dalam kekayaan yang berkembang. Menurut mereka kebutuhan merupakan persoalan pribad yang tidak bisa dijadikan ukuran.

Oleh karena itu setiap yang diinginkan oleh manusia tidaklah bisa disebut sebagai kebutuhan rutin manusia itu berubah-rubah dan berkembang sesuai dengan perubahan zaman, situasi, dan kondisi setempat.

5. Bebas dari Hutang.

Pemilikan sempurna yang dijadikan persyaratan wajib zakat dan harus lebih dari kebutuhan primer di atas haruslah pula cukup senisab yang sudah bebas dari hutang.

Bila pemilik mempunyai hutang yang menghabiskan atau mengurangi jumlah senisab itu, zakat tidaklah wajib. Syarat yang tidak diperselisihkan lagi adalah bahwa hutang itu menghabiskan atau mengurangi jumlah senisab, sedangkan yang lain tidak ada lagi untuk mengganti atau untuk mengembalikannya.

6. Berlalu Setahun

Maksud dari berlalu setahun adalah bahwa kepemilikan yang berada di tangan si pemilik sudah berlalu masanya dua belas bulan Qamariah. Persyaratan ini hanya berlaku pada ternak, uang dan harta dagang. Sedangkan hasil pertanian, buah-buahan, madu, logam mulia, rikaz danlainnya yang sejenis dengan itu tidak diisyaratkan harus satu tahun.

Untuk menunaikan zakat pertanian ada beberapa syarat yang harus dipenuhi yakni: Pertama, merupakan hasil pertanian yang ditanam sendiri oleh manusia, Kedua, hasil pertanian merupakan jenis makanan pokok manusia yang 
dapat disimpan dan jika disimpan tidak rusak, Ketiga, sudah mencapai nisab, nisab dihitung sendiri-sendiri sesuai dengan jenis tanamannya.

Zakat merupakan bagian dari pendapatan masyarakat yang berkecukupan yang menjadi hak dan karena itu harus diberikan kepada yang berhak, yakni untuk memberantas kemiskinan dan penindasan. Dalam rukun zakat terdapat ketentuan bahwa zakat tidak boleh diberikan kepada mereka yang wajib zakat dan hukumnya haram, kecuali mereka yang sesuai dalam kriteria delapan asnaf. ${ }^{2}$

Dalam Al-Quran kata infak, shadaqah dan hak walaupun mempunyai kata yang berbeda tetapi sering disebut dengan kata yang sama, yaitu zakat, karena mempunyai esensi yang sama. Bahkan zakat harus dibagikan kepada delapan asnaf, sebagaimana dinyatakan oleh Allah dalam surat At-Taubah ayat 60 .

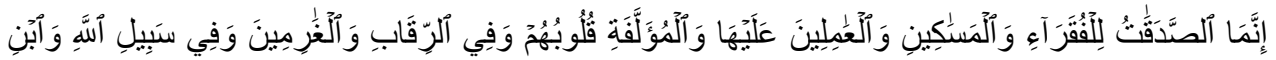

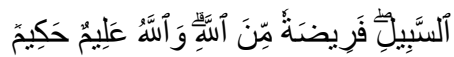

Artinya: "Sesungguhnya zakat itu hanyalah untuk orang-orang fakir, orang miskin, amil zakat, yang dilunakkan hatinya (mualaf), untuk (memerdekakan) hamba sahaya, untuk (membebaskan) orang yang berhutang, untuk jalan Allah dan untuk orang yang sedang dalam perjalanan, sebagai kewajiban dari Allah. Allah Maha Mengetahui, Maha Bijaksana. (QS. At-Taubah : 60).

Berdasarkan ayat di atas maka 8 golongan yang berhak menerima zakat (mustahiq) adalah sebagai berikut:

1) Fakir adalah orang yang melarat hidupnya karena ketiadaan sarana (harta) dan prasarana (tenaga) untuk memenuhi kebutuhan hidupnya.

2) Miskin adalah orang yang serba kekurangan, tidak pernah terpenuhi kebutuhan hidupnya, meskipun mungkin sudah berusaha secara maksimal.

3) Amil adalah pengurus atau pengelola zakat yang bertugas mengumpulkan dan mendistribusikan harta zakat kepada para mustahik.

4) Mu'eallaf adalah orang yang terbujuk hatinya masuk Islam atau orang yang mempunyai potensi memeluk agama Islam.

5) Riqab adalah budak atau tawanan perang dalam rangka membebaskan merekadari perbudakan atau penawanan.

6) Gharim adalah orang yang terililit hutang dan dia tidak bisa melunasi hutangnya kecuali dengan bantuan orang lain. Hutang itu muncul karena usaha atau kegiatan halal yang kemudian karena salah perhitungan dia

${ }^{2}$ Dawam Raharjo, Islam dan Transformasi Sosial-Ekonomi, Yogyakarta : Pustaka Pelajar, cet.1, 1999, hlm, 446. 
348 | TAZKIR: Jurnal Penelitian Ilmu-ilmu Sosial dan Keislaman

Vol. 04 No. 2 Desember 2018

kemudian jadi bangkrut dan menjadi banyak hutang. Tidak ada zakat bagi orang yang terlilit hutang akibat kegiatan maksiat, berjudi dan semacamnya.

7) Sabilillah adalah jihad dan dakwa Islam, baik secara individu (perorang) maupun secara kolektif (dalam bentuk lembaga atau organisasi dakwa).

8) Ibnu sabil musafir yang kehabisan bekal untuk melanjudkan perjalanannya.

Dengan demikian bahwa zakat itu tidak dapat diberikan kepada sembarang orang berdasarkan pilihan si muzakki, melainkan kepada yang sudah ada ketentuannya berdasarkan Al-Qur, an tersebut.

Zakat merupakan ibadah dan kewajiban sosial bagi para aqhniya' (hartawan) setelah kekayaannya memenuhi batas minimal atau nisab dan rentang waktu setahun (haul). Tujuannya untuk mewujudkan pemerataan keadilan dalam ekonomi. ${ }^{3}$ Dalam figh juga telah ditetapkan secara jelas mengenai ketentuan-ketentuan tentang jenis-jenis harta zakat, nisab, haul, cara kerja amil, baitul mal, mustahiq dan lain-lain. Sehingga zakat merupakan salah satu bentuk dari tanggung jawab sosial bagi mereka yang memiliki harta yang melebihi tingkat tertentu (nisab). ${ }^{4}$

Dalam pelaksanaan pembayaran zakat pertanian padi di Kec Huristak Kab Padang Lawas peneliti melihat berbeda dengan cara pembayaran zakat pada umumnya, di kecamatan huristak itu para petani dalam memberikan zakatnya menentukan sendiri orang yang menjadi mustahiqnya, biasanya adalah kategori miskin dan fisabilillah karena memang dua kategori itulah yang ada disana apalagi amil yang ditentukan secara resmi belum ada.

Setelah petani tersebut menentukan siapa yang menjadi mustahiq zakatnya lalu memanggilnya kerumah yang bersangkutan dan disampaikanlah ijab qabulnya yang kira-kira sebagai berikut:

Artinya: "Saya serahkan zakat padiku kepadamu 12 kaleng panen kali ini, saya terima zakat padimu 12 kaleng, yang 12 kaleng ini saya ambillah 2 kaleng bagian saya sebagai pertanggung jawaban, dan selabihnya saya serahkan kepadamu dan pergunakanlah untuk keperluanmu apa yang dirasa perlu terrmasuk membayar hutang-hutangmu"5

3 Ahmad Rafiq, Fiqh Kontekstual : Dari Normatif ke Pemaknaan Sosial, Yogyakarta : Pustaka Pelajar, Cet. Ke-1, 2004, hlm. 259

4 Tim Pengembangan Perbankan Syari'ah Institut Bankir Indonesia, Bank Syari'ah : Konsep, Produk dan Implementasi Operasional, Jakarta : Jambatan, 2001, hlm. 18.

${ }^{5}$ Hasil Wawancara dengan Bapak H. Rahmat siregar, salah satu petani dan pemuka Agama yang berdomisili di kecamatan huristak kab padang lawas, Tgl 9 Desember 2017 lewat HP. 
Dari tradisi yang berlalu ditengah masyarakat tersebut dimana para petani setelah memberikan zakatnya kepada yang mustahiq, kemudian mustahiq tersebut mengambil bagiannya $1 / 8$ dari zakat yang diterimanya selebihnya menyerahkan kembali kepada muzakki untuk dapat dipergunakan sesuai dengan kebutuhannya. Dan biasanya kalau mustahiq tidak menyerahkan sebagian kembali kepada si muzakkinya maka mustahiq tersebut akan menjadi ocehan orang dimasyarakat dan simuzakki tersebut tidak akan mau memberikan zakat kepadanya pada saat panen selanjutnya.

\section{KAJIAN TEORITIS}

\section{Mustahiq Zakat.}

Sebagaimana firman Allah swt dalam surah At-Taubah ayat 60, sebagaimana berikut ini:

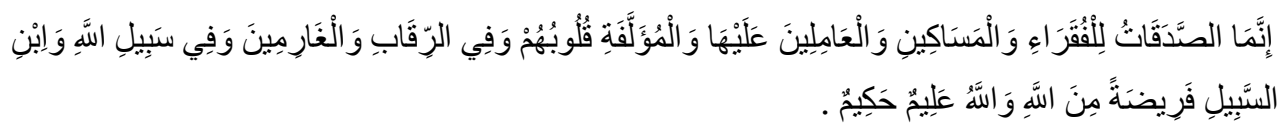

Artinya: "Sesungguhnya zakat itu hanyalah untuk orang-orang fakir, orang-orang miskin, pengurus-pengurus zakat, para muallaf, yang dibujuk hatinya,untuk (memerdekakan) budak, orang-orang yang berutang, untuk jalan Allah, dan orang-orang yang sedang dalam perjalanan, sebagai suatu ketetapan yang diwajibkan Allah. Dan Allah Lagi Maha Mengetahui Lagi Maha Bijaksana." (Q.S. At-Taubah:60).

Ayat tersebut menjelaskan tentang golongan atau kelompok yang berhak menerima zakat (mustahik zakat). Ibnu Katsir ketika menafsirkan ayat di atas dalam kitabnya sebagaimana dikutip oleh Abdul Azhim, menjelaskannya sebagai berikut, "Tatkala Allah swt menyebutkan penentangan orang-orang munafik yang bodoh itu atas penjelasan Nabi saw. dan mereka mengecam beliau mengenai pembagian zakat, maka kemudian Allah menerangkan dengan tegas bahwa Dialah yang membaginya, Dialah yang menetapkan ketentuannya, dan Dia pula yang memproses ketentuan-ketentuan zakat itu sendirian, tanpa campur tangan siapapun. Dia tidak pernah menyerahkan masalah pembagian ini kepada siapapun selain Dia. Maka Dia membagi-bagikan kepada orang-orang yang telah disebutkan dalam ayat di atas."6

Berikut ini adalah kelompok atau golongan (ashnaf) yang berhak menerima

${ }^{6}$ Abdul 'Azhim bin Badawi al-Khalafi, al-Wajiz Ensiklopedi Fikih Islam dalam Al-Qur'an dan As-SunnahAsh-Shahihah, (terj. Ma'ruf Abdul Jalil), (Solo: Pustaka As-Sunnah, 2006), hlm. 439 
350 | TAZKIR: Jurnal Penelitian Ilmu-ilmu Sosial dan Keislaman

Vol. 04 No. 2 Desember 2018

zakat yaitu sebagai berikut:

1. Fakir dan miskin

Kelompok pertama yang berhak menerima bagian zakat adalah alFuqara'. Dari segi bahasa al-Fuqara' adalah bentuk jamak dari kata al-faqir, menurut mazhab Syafi'i dan Hanbali al-faqir adalah orang yang tidak memiliki harta benda dan pekerjaan untuk mencukupi kebutuhannya seharihari, sehingga ia kesulitan memenuhi kebutuhannya. Sedangkan al-Masakin adalah bentuk jama' dari al-miskin yaitu orang yang memiliki pekerjaan tetapi penghasilannya tidak dapat dipakai untuk memenuhi hajat hidupnya ${ }^{7}$ (Wahbah az-Zuhaily, 2008: 280-281). Jumhur Ulama berpendapat bahwa fakir dan miskin adalah dua golongan tapi satu macam. Yang dimaksud adalah mereka yang kekurangan dan dalam kebutuhan. Tetapi para ahli tafsir dan ahli fiqih berbeda pendapat pula dalam menentukan secara definitif arti kedua kata tersebut secara tersendiri, juga dalam menentukan apa makna kata itu.

Imam ath-Thabari menegaskan bahwa, yang dimaksud dengan fakir adalah orang yang dalam kebutuhan, tapi dapat menjaga diri tidak memintaminta. Sedang yang dimaksud dengan miskin, yaitu orang yang dalam kebutuhan, tapi suka merengek-rengek dan minta-minta. Diperkuatnya lagi pendapatnya itu dengan berpegang pada arti kata maskanah (kemiskinan jiwa) yang sudah menunjukkan arti demikian. ${ }^{8}$

Walaupun kedua kelompok ini kelihatannya sama-sama hidup dalam kesulitan, tetapi sesungguhnya kedua kelompok ini memiliki perbedaan yang cukup signifikan, akan tetapi dalam teknis opersional sering dipersamakan, yaitu mereka yang tidak memiliki penghasilan sama sekali, atau memilikinya akan tetapi sangat tidak mencukupi kebutuhan pokok dirinya dan keluarga yang menjadi tanggungannya. Zakat yang disalurkan pada kelompok ini dapat bersifat konsumtif, yaitu untuk memenuhi kebutuhan sehari-hari dan dapat pula bersifat produktif, yaitu untuk menambah modal usahanya. ${ }^{9}$

2. Amil (pengurus zakat)

\footnotetext{
${ }^{7}$ Wahbah Az-Zuhaily, al-Figh al-Islam wa Adillatuhu, Cet. 3,( Beirut: Dar al- Fikr,1989), hlm. 280-281

${ }^{8}$ Abdul 'Azhim bin Badawi al-Khalafi, al-Wajiz, hlm. 439

${ }^{9}$ Didin Hafidhuddin, 2002. Zakat Dalam Perekonomian Modern, (Jakarta, Gema Insani
} Press, 2002), hlm. 149 
Kata 'Amilin adalah bentuk jamak dari 'amil yang artinya beramal atau bekerja. 'Amil adalah orang-orang yang bekerja memungut zakat, yang terdiri dari Su'at/ jubbat (pengumpul), qassam (pembagi/ distributor), katabat (pencatat), khazanah (penjaga), ru'at (pengembala hewan zakat). Intinya bahwa amil adalah petugas perzakatan (Shalehuddin, 2011: 194). Adapun syarat yang harus dipenuhi oleh Amilin adalah sebagai berikut (Shalehuddin, 2011: 195) :

a. Mukallaf

b. Muslim

c. Jujur

d. Memahami hukum-hukum zakat

e. Terampil (memiliki kemampuan untuk melaksanakan tugas)

f. Tidak termasuk orang yang haram menerima zakat.

Amil tetap diberi zakat walaupun ia kaya karena yang diberikan kepadanya adalah imbalan kerjanya bukan merupakan pertolongan bagi yang membutuhkan. Kelompok amil zakat berhak mendapat bagian dari zakat, maksimal $1 / 8$ atau $12,5 \%$, dengan catatan bahwa petugas zakat ini memang melakukan tugas-tugas keamilan dengan sebaik-baiknya dan waktunya sebagian besar atau seluruhnya untuk tugas tersebut. Jika hanya di akhir bulan ramadhan saja (dan biasanya hanya untuk pengumpulan zakat fitrah saja), maka seyogianya tidak mendapatkan bagian zakat 1/8, melainkan hanyalah sekedarnya saja untuk keperluan administrasi ataupun konsumsi yang mereka butuhkan, misalnya 5\% saja. Bagian untuk amil inipun termasuk untuk biaya transportasi maupun biaya-biaya lain yang dibutuhkan untuk melaksakan tugasnya. (Abdul Karim, 2015: 14)

3. Muallaf (orang-orang yang dibujuk hatinya)

Yang dimaksud dengan golongan muallaf ini adalah mereka yang diharapkan kecenderungan hatinya atau keyakinannya dapat bertambah terhadap Islam, atau terhalang niat jahatnya kepada kaum muslimin, atau harapan adanya kemanfaatan mereka dalam membela dan menolong kaum muslimin. Ini berarti bahwa zakat dalam pandangan Islam bukan sekedar perbuiatan baik yang bersifat kemanusiaan dan bukan sekedar ibadah yang dilakukan secara pribadi, tetapi juga merupakan tugas bagi mereka yang berwenang untuk mengurus zakat terutama kepada sasaran zakat yang diperuntukkan untuk muallaf ini (Qardawi, 2011: 263). 
352 | TAZKIR: Jurnal Penelitian Ilmu-ilmu Sosial dan Keislaman

Vol. 04 No. 2 Desember 2018

Muallaf yaitu kelompok orang yang dianggap masih lemah imannya, karena baru masuk Islam. Mereka diberi zakat agar bertambah kesungguhan dalam memeluk Islam dan bertambah keyakinan mereka, bahwa segala pengorbanan mereka dengan masuk Islam tidak sia-sia. Dengan menempatkan golongan ini sebagai sasaran zakat, maka jelas bagi kita bahwa zakat dalam pandangan Islam bukan sekedar perbuatan baik yang bersifat kemanusiaan melulu dan bukan pula sekedar ibadah yang dilakukan secara pribadi, akan tetapi juga merupakan tugas penguasa atau mereka yang berwewenang untuk mengurus zakat. ${ }^{10}$

4. Riqab (Hamba sahaya)

Riqab adalah bentuk jama' dari raqabah, dalam al-Qur'an istilah ini berarti budak belian laki-laki. Istilah ini diterangkan dalam kaitannya dengan pembebasan atau pelepasan, seolah-olah al-Qur'an memberikan isyarat bahwa perbudakan harus dihapuskan dengan memberikan kebebasan kepanya. Artinya bahwa zakat itu di antaranya harus dipergunakan untuk membebaskan budak dan menghilangkan praktek perbudakan (Qardawi, 2011: 587). Riqab adalah golongan mukatab yang ingin membebaskan diri, artinya budak yang telah dijanjikan oleh tuannya akan dilepaskan jika ia dapat membayar sejumlah tertentu dan termasuk pula budak yang belum dijanjikan untuk memerdekakan dirinya. (Fatimah Ismail, 2000: 5).

Adapun cara membebaskan perbudakan ini biasanya dilakukan dua hal, yaitu (Qardawi, 2011: 587-588): Menolong untuk pembebasan diri hamba mukatab, yaitu budak yang telah membuat kesepakatan dan perjanjian dengan tuannya, bahwa apabila ia sanggup membayar sejumlah harta dengan jumlah tertentu maka ia dapat membebaskan dirinya.

Seseorang atau sekelompok orang dengan memberikan uang zakatnya atau petugas zakat dengan uang zakat yang telah terkumpul dari para muzakki untuk membeli budak/ hamba sahaya kemudian dibebaskan.

Oleh karena golongan ini sekarang sudah tidak ada lagi, maka zakat mereka itu dialihkan kepada mustahik lainnya, demikian menurut pendapat mayoritas ulama fiqh (jumhur). Namun, sebagian ulama berpendapat bahwa

${ }^{10}$ Didin Hafidhuddin, 2002. Zakat Dalam Perekonomian Modern, (Jakarta, Gema Insani Press, 2002), hlm. 5 
golongan ini masih ada, yaitu para tentara muslim yang menjadi tawanan (Hikmat Kurnia, 2008: 146).

5. Gharimin (orang-orang yang memiliki hutang)

Gharimin adalah bentuk jama' dari gharim artinya adalah orang yang berutang. Gharim menurut bahasa adalah tetap, disebut ia sebagai gharim karena utang telah tetap kepadanya atau tetap kepadanya orang yang mempunyai piutang. Menurut mazhab Abu Hanifah, gharim adalah orang yamg mempunyai utang dan dia tidak mempunyai bagian yang lebih dari utangnya. Sedangkan menurut imam Malik, Syafi'i dan Ahmad membagi 2 model orang yang mempunyai utang. Pertama, orang yang mempunyai utang untuk kemaslahatan dirinya sendiri. Kedua, orang yang mempunyai utang untuk kemaslahatan masyarakat (Qardawi, 2011: 594-595).

Gharim adalah orang-orang yang menanggung hutang dan tidak sanggup untuk membayarnya karena telah jatuh miskin. Mereka bermacammacam di antaranya orang yang mendapat berbagai bencana dan musibah, baik pada dirinya maupun pada hartanya, sehingga mempunyai kebutuhan mendesak untuk berhutang bagi dirinya dan keluarganya (Sayyid Sabiq, 1978: 120).

Abdul Karim Golongan ini diberi zakat dengan syarat-syarat sebagai berikut yaitu : Hutang itu tidak timbul karena kemaksiatan Orang tersebut berhutang dalam melaksanakan ketaatan atau mengerjakan sesuatu yang dibolehkan oleh syariat.

a. Sipengutang tidak sanggup lagi melunasi utangnya.

b. Utang itu telah jatuh tempo, atau sudah harus dilunasi ketika.

c. zakat itu diberi kepada si pengutang.

Orang yang berhutang karena kemaslahatan dirinya harus diberi sesuai dengan kebutuhannya, yaitu untuk membayar lunas hutangnya. Apabila ternyata ia dibebaskan oleh orang yang memberi hutang, maka ia harus mengembalikan bagiannya itu.

6. Fi sabilillah

Menurut bahasa sabil berarti thariq/ jalan. Sabilillah artinya adalah jalan yang menyampaikan kepada ridha Allah swt, baik akidah ataupun perbuatan. Biasanya kalimat ini digunakan untuk makna jihad (berperang di jalan Allah). Menurut Mazhab Hanafi, sabilillah itu adalah sukarelawan yang terputus bekalnya. Imam Maliki sabilillah adalah tentara yang berperang. 
354 | TAZKIR: Jurnal Penelitian Ilmu-ilmu Sosial dan Keislaman

Vol. 04 No. 2 Desember 2018

Imam syafi'i berpendapat bahwa sabilillah adalah para sukarelawan yang tidak mendapat tunjangan tetap dari pemerintah, sedangkan imam Ahmad menjelaskan bahwa sabilillah adalah sukarelawan yang berperang yang tidak memiliki gaji tetap atau memiliki tetapi tidak mencukupi kebutuhan (Qardawi, 2011: 610-616).

Kesimpulannya bahwa sabilillah adalah orang yang berjuang di jalan Allah dalam pengertian luas sesuai dengan yang ditetapkan oleh para ulama fikih. Intinya adalah melindungi dan memelihara agama serta meniggikan kalimat tauhid, seperti berperang, berdakwah, berusaha menerapkan hukum Islam. Golongan yang termasuk dalam katagori fi sabilillahadalah, da'i, suka relawan perang yang tidak mempunyai gaji, serta pihak-pihak lain yang mengurusi aktifitas jihad dan dakwah (Hikmat Kurnia \& Hidayat, 2008: 146).

Pada zaman sekarang bagian fi sabilillah dipergunakan untuk membebaskan orang Islam dari hukuman orang kafir, bekerja mengembalikan hukum Islam termasuk jihad fisabilillahdiantaranya melalui pendirian pusat Islam yang mendidik pemuda muslim, menjelaskan ajaran Islam yang benar, memelihara aqidah dan kekufuran serta mempersiapkan diri untuk membela Islam dari musuh-musunya.

7. Ibnu sabil

Ibnu Sabil menurut jumhur ulama adalah kiasan untuk musafir yaitu orang yang melintas dari satu daerah ke daerah lain (Qardawi, 2011: 645). Ibnu sabil adalah orang yang terputus bekalnya dalam perjalanan, untuk saat sekarang, di samping para musafir yang mengadakan perjalanan yang dianjurkan agama. Ibnu sabil sebagai penerima zakat sering dipahami dengan orang yang kehabisan biaya diperjalanan ke suatu tempat bukan untuk maksiat. Tujuan pemberian zakat untuk mengatasi ketelantaran, meskipun di kampung halamannya ia termasuk mampu.

Dengan demikian, dapat dipahami bahwa Islam memberikan perhatian kepada orang yang terlantar. Penerima zakat pada kelompok ini disebabkan oleh ketidakmampuan yang sementara. Para ulama sepakat bahwa mereka hendaknya diberi zakat dalam jumlah yang cukup untuk menjamin mereka pulang. Pemberian ini juga diikat dengan syarat bahwa perjalanan dilakukan atas alasan yang bisa diterima dan dibolehkan dalam Islam. Tetapi jika musafir itu orang kaya di negerinya dan bisa menemukan seseorang yang meminjaminya uang, maka zakat tidak diberikan kepadanya. 
Golongan ini diberi zakat dengan syarat-syarat sebagai berikut yaitu11 Sedang dalam perjalanan di luar lingkungan negeri tempat tinggalnya. Jika masih di lingkungan negeri tempat tinggalnya, lalu ia dalam keadaan membutuhkan, maka ia dianggap sebagai fakir atau miskin. Perjalanan tersebut tidak bertentangan dengan syari'at Islam, sehingga pemberian zakat itu tidak menjadi bantuan untuk berbuat maksiat.

Pada saat itu ia tidak memiliki biaya untuk kembali ke negerinya, meskipun di negerinya sebagai orang kaya. Jika ia mempunyai piutang belum jatuh tempo, atau kepada orang lain yang tidak diketahui keberadaannya, atau kepada seseorang yang dalam kesulitan keuangan, atau kepada orang yang mengingkari hutangnya, maka semua itu tidak menghalanginya.

Allah menerangkan sasaran zakat dalam Qur'an dan menghususkan pada delapan sasaran, wajibkah bagi orang yang memberikan zakat, baik sipemilik langsung atau penguasa untuk membagikan pada semua sasaran zakat yang delapan, dan menyamakan pembagian diantara mereka.

Imam nawawi telah berkata dalam Al Majmu'12 Imam Asy-Syafi'i dan ashabnya telah berpendapat bahwa apabila yang membagikan itu pemilik langsung atau yang wakilnya, maka hilanglah hilanglah bagian untuk petugas, dan ia wajib membagikan zakat itu pada tujuh golongan yang lain, apabila semua ada, dan apabila tidak maka wajib diberikan pada semua yang ada,tidak diperbolehkan membiarkan salah satu golongan yang ada sehingga apabila ia melakukan, ia harus bertanggung jawab terhadap bagiannya itu.

Terhadap pendapat mazhab itu dalam menyamaratakan pembagian zakat pada semua golongan, diikuti pula oleh Ikrimah, Umar bin Abdul Aziz, Ad Zuhri dan Daud.

Terdapat pula satu riwayat, dari Imam Ahmad, bahwa wajib menyamaratakan dan mempersamakan pembagian zakat itu diantara semua golongan, dan hendaknya setiap golongan itu tiga orang atau lebih karena jumlah tiga itu adalah minimal jumlah jamak, kecuali petugas, karena apa yang dikembalikan merupakan upah baginya, sehingga diperbolehkan walaupun seorang saja. Dan apabila pemilik langsung yang membagikan hlm. 9

11 Yasin Ibrahim, Zakat Penyempurna Puasa Pembersih Harta, (Bandung: PT. Marjan, 2008),

12 Al Majmu' Jilid 6, hlm, 185 
356 | TAZKIR: Jurnal Penelitian Ilmu-ilmu Sosial dan Keislaman

Vol. 04 No. 2 Desember 2018

zakat, maka hilanglah bagian petugas. Inilah pendapat yang dipilih Abu Bakr dari Mazhab Hambali.

Imam Ushbug dari Mazhab Maliki setuju dengan pendapat Mazhab Syafi'i dalam menyamaratakan semua golongan, sehingga tidak perlu penjelasan lagi dalam memberikan bagian pada mereka, dan karena dengan itu tercakup semua kemaslahatan yang bermacam-macam, seperti untuk menutupi kekurangan, keperluan perang, membayar utang dan lain sebagainya. Dan karena itu menyebabkan adanya do'a dari semua sasaran.

Imam Malik, abu hanifah dan golongannya telah berbeda pendapat dengan imam asy-syafi'i, mereka tidak mewajibkan pemberian zakat pada semua sasaran. Mereka berkata "sesungguhnya lam (li) pada ayat itu bukan lam tamlik, akan tetapi lammul ajli (lam menunjukkan karena sesuatu), seperti ucapan: pelana itu untuk kuda dan pintu itu untuk rumah. Mereka beralasan dengan firmal Allah QS.

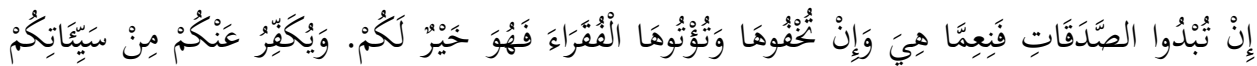

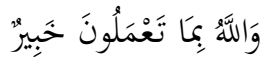

Artinya: "Jika kamu Menampakkan sedekah(mu) Maka itu adalah baik sekali. dan jika kamu menyembunyikannya dan kamu berikan kepada orang-orang fakir, Maka Menyembunyikan itu lebih baik bagimu. dan Allah akan menghapuskan dari kamu sebagian kesalahan-kesalahanmu; dan Allah mengetahui apa yang kamu kerjakan.

Alah tidak menerangkan sasaran lain dalam ayat itu kecuali orangorang fakir. Sedangkan sedekah dalam qur'an, apabila dimutlakka, maksudnya tidak lain sedekah wajib.

Abu Ubaid telah menerima riwayat dari Ibnu Abbas, bahwa ia berkata: "apabila engkau memberikan zakat pada satu sasaran dari sasaran zakat itu, maka hal itu cukup bagimu, dan sesungguhnya Allah berfirman: "Sesungguhnya sedekah itu hanyalah untuk orang-orang fakir dan orang-orang miskin dan seterusnya..," maksudnya agar sedekah itu jangan diberikan kepada selain sasaran yang sudah ditetapkan tersebut.

\section{METODE PENELITIAN}

Penelitian ini adalah penelitian lapangan (field research) yaitu penelitian yang obyeknya mengenai gejala-gejala atau peristiwa yang terjadi pada masyarakat dan dipadukan dengan kepustakaan. Peneliti dalam hal ini 
menggunakan penelitian deskriptif, yaitu hanya sekedar untuk melukiskan atau menggambarkan sejumlah variabel yang berkenaan dengan masalah yang diteliti, unit yang ditelaahnya individu dengan menggunakan pendekatan studi kasus. Dalam hal ini mengenai pelaksanaan zakat hasil pertanian di Kec Huristak Kab Padang Lawas. Penelitian ini menggunakan data primer dan data sekunder; sementara data primer adalah data yang diproleh atau yang dikumpulkan langsung dari lapangan oleh peneliti berkaitan dengan data-data yang diperlukan. ${ }^{13}$ Data primer ini diperoleh dari orang-orang yang menjadikan informan penelitian ini, yaitu masyarakat khususnya para petani, Tokoh Agama, Tokoh Adat, lembaga pemerintahan yang berwenang dalam hal ini Kepala Kantor Urusan Agama Kec Huristak, orang-orang yang berpendidikian tinggi. Data sekunder adalah data yang diperoleh lewat pihak lain, tidak langsung diperoleh oleh peneliti dari subyek penelitiannya.' di antaranya dari buku-buku literatur dan media lainnya yang berhubungan dengan masalah yang akan dibahas dalam penelitian ini, data ini juga digunakan sebagai pelengkap data primer. ${ }^{14}$

Dalam metode pengumpulan data ini, peneliti akan menggunakan salah satu metode pengumpulan data yang lazim digunakan dalam penelitian sosial, yaitu Wawancara. Dalam hal ini yang menjadi responden adalah masyarakat petani yang berada di Kec Huristak Kab Padang Lawas, para tokoh agama, tokoh adat, lembaga pemerintah dalam hal ini Kepala Kantor Urusan Agama Kec Huristak, orang yang berpendidikan tinggi, dan sebagainya. Wawancara dilakukan dengan terbuka, artinya penelitian hanya menyediakan daftar pertanyaan secara garis besar dan para responden diberikan keleluasaan dalam memberikan jawabannya.

\section{HASIL PENELITIAN DAN PEMBAHASAN}

\section{Pemahaman Masyarakat Terhadap Mustahiq Zakat Padi}

Al-Qur'an menjelaskan tentang siapa saja yang berhak menerima zakat. Hal ini tentu merupakan perhatian Al-Qur'an secara spesifik kepada siapa zakat itu harus diberikan. Sebagaimana firman Allah swt dalam surah At-Taubah ayat 60, sebagaimana berikut ini:

${ }^{13}$ Iqbal Hasan, Analisis Data Penelitian Dengan Statistik, (Jakarta: Bumi Aksara, 2008), h, 19.

${ }_{14}$ Suharsini Arikunto, Prosedur Penelitian Suatu Pendekatan Praktek, Cet. Ke-12, Jakarta: Rineka Cipta, 2002, h, 236 
358 | TAZKIR: Jurnal Penelitian Ilmu-ilmu Sosial dan Keislaman

Vol. 04 No. 2 Desember 2018

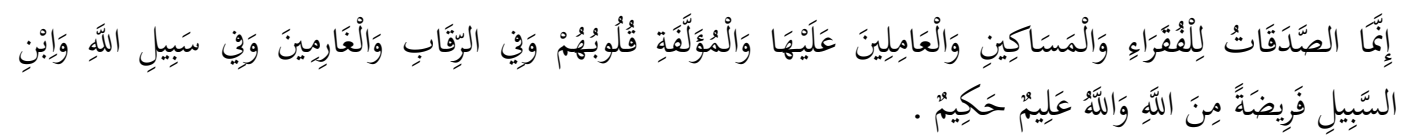

Artinya: "Sesungguhnya zakat itu hanyalah untuk orang-orang fakir, orang-orang miskin, pengurus-pengurus zakat, para muallaf, yang dibujuk hatinya,untuk (memerdekakan) budak, orang-orang yang berutang, untuk jalan Allah, dan orang-orang yang sedang dalam perjalanan, sebagai suatu ketetapan yang diwajibkan Allah. Dan Allah Lagi Maha Mengetahui Lagi Maha Bijaksana." (Q.S. At-Taubah

Ayat tersebut menjelaskan tentang golongan atau kelompok yang berhak menerima zakat (mustahik zakat). Ibnu Katsir ketika menafsirkan ayat di atas dalam kitabnya sebagaimana dikutip oleh Abdul Azhim, menjelaskannya sebagai berikut, "Tatkala Allah swt menyebutkan penentangan orang-orang munafik yang bodoh itu atas penjelasan Nabi saw. dan mereka mengecam beliau mengenai pembagian zakat, maka kemudian Allah menerangkan dengan tegas bahwa Dialah yang membaginya, Dialah yang menetapkan keten tuannya, dan Dia pula yang memproses ketentuan-ketentuan zakat itu sendirian, tanpa campur tangan siapapun. Dia tidak pernah menyerahkan masalah pembagian ini kepada siapapun selain Dia. Maka Dia membagi-bagikan kepada orang-orang yang telah disebutkan dalam ayat di atas.". ${ }^{15}$

Masyarakat Tobing Julu dalam memahami mustahiq zakat mayoritas tidaklah berdasarkan apa yang dijelaskan oleh Allah dan Rasulullah SAW, dimana masyarakat setempat perpedoman hanya kepada kebiasaan saja. Berdasarkan hasil wawancara yang dilkukan oleh penulis terhadap beberapa orang petani, mereka mengatakan bahwa kebiasaanya memberikan zakat padi itu hanya kepada malim kampong yang ada. Sedangkan mustahiq yang lain yang ditetapkan dalam Al-Qur'an walaupun ada di tempat itu, akan tetapi karena tidak biasa diberikan seperti itu, maka para petani sangat jarang untuk memberikannya terkecuali hanya para petani yang mengetahui siapa-siapa yang berhak untuk dapat diberikan zakat padi tersebut.

${ }^{15}$ Abdul 'Azhim bin Badawi al-Khalafi, al-Wajiz, hlm. 439 


\section{Pembahasan}

Analisis Terhadap Mustahiq Zakat Padi di Kec. Huristak Kab. Padang Lawas

Penelitian yang penulis lakukan di Kec. Huristak Kab Padang Lawas telah memberikan indikasi bahwa Pelaksanaan zakat pertnian padi masih jauh dari apa yang tertuang dalam Al-Qur'an dan sunnah rasul, melainkan hanya berpegangan kepada tradisi orang terdahulu yang tidak jelas darimana sumber hukumnya.

Informan yang penulis maksud adalah khusus para petani padi telah berkewajiban mengeluarkan zakat penghasilannya dari usaha komoditasnya (padi). Dari obserpasi yang penulis lakukan ke lapangan bahwa masyarakat Kec. Huristak Kab. Padang Lawas yang berdomisili disana rata-rata sumber penghidupannya berasal dari bertani khususnya padi.

Berikut ini pelaksanaan zakat hasil pertanian padi yang telah diberikan kepada masing-masing informan.

Pertama, penulis akan melihat bagaimana pelaksanaan zakat hasil pertanian padi. dari sisi pernah atau tidaknya informan mendengar zakat pertanian padi. Berdasarkan hasil wawancara penulis, kepada informan hampir semua pernah mendengar atau mengetahui kewajiban zakat hasil pertanian padi, Baik itu dari sesama teman, Alim ulama, dan lain sebagainya.

Kedua, penulis menayakan pernah atau tidaknya informan mengeluarkan zakat hasil petani padi. Sebagai dasar tolak ukur untuk melihat sejauh mana pelaksanaan zakat hasil petani padi dalam memahami dan menjalankan hukum zakat.

Dari data di atas, membuktikan pelaksanaan zakat hasil petani padi dititik beratkan pada pemahaman.Yaitu petani dalam memahami hukum zakat, khususnya zakat pertanian padi memang sungguh sangat lemah. Sehingga pelaksanaan yang muncul dari ide mereka, berdasarkan kebiasaan orang- orang terdahulu. hasil wawancara penulis dengan St. Nabuttu Harahap: ${ }^{16}$

Artinya: "Saya yang tau memberikan zakat hasil pertanian padi kepada Alim Ulama yang ada disini, setelah saya berikan lalu dia memberikan sebagian lagi kepada saya, ya, saya terima katanya untuk membayarkan kalau ada hutang-hutang saya gitu."

${ }^{16}$ St. Nabuttu Harahap, Petani Padi, Hasil Wawancara Pribadi, 13 Juni 2018. 
360 | TAZKIR: Jurnal Penelitian Ilmu-ilmu Sosial dan Keislaman

Vol. 04 No. 2 Desember 2018

Pemahaman seperti ini yang masih berlaku di sebagian informan, mengakibatkan menjadi tradisi bagi masyarakat Kec. Huristak Kab. Padang Lawas. Sekalipun zakat yang sudah diberikan kepada orang yang mustahiq sudah menjadi hak penuh oleh mustahiqnya namaun bagi para petani masih tetap mengi-nginkan agar mustahiqnya tetap memberikan sebahagian lagi kepada muzakkinya.

Ketiga, alasan mustahiq mengembalikan hak zakatnya kepada muzakki setelah mengambilnya sebagian di Kec. Huristak Kab Padang Lawas. Dari masing-masing para petani padi yang sudah berkewajiban membayar zakat penghasilannya (cukup nisab). Mustahiq mengatakan zakat itu hak kita hanya 1/8 saja, sedangkan selebihnya adalah menjadi hak orang lain, oleh karena mustahiq tidak bisa memberikan kepada mustahiq yang sebagian lagi maka zakat dikembalikan kepada muzakki agar dapat diberikan kepada yang lain. Berdasarkan wawan cara penulis dengan salah satu Mustahiq zakat di Desa Gala Bonang sebagai salah satu Desa di Kec Huristak:

Malim Kari Siregar" yang berhak menerima zakat kan ada 8 kategori, saya salah satunya sebagai Ibn Sabil karena saya mengajar mengaji dikampung ini, jadi ketika ada orang berzakat saya terima semuanya kemudian saya bilang kepada muzakkinya dari semua zakat ini saya ambil 1/8 saja selabihnya saya berikan kepada orang yang berzakat itu agar dibagikannya kepada mustahiq lainnya, termasukla orang yang berzakat itu sendiri kalau dia mempunyai hutanghutangnya karena dia termasuk kategori Ghorimin (orang berhutang)

Dari data tersebut bahwa penulis berpendapat dari Pelaksanaan zakat pertanian padi di Kec. Huristak Kab. Padang Lawas, ini banyak dipengaruhi oleh unsur masa lalu yang tidak jelas dari mana asal mausulnya. Dalam hal ini, kebiasaan masyarakat yang mengikuti aktifitas kebiasaan orang-orang terdahulu yang menyerahkan dan menerima zakat hasil pertanian padi itu. Ini berakar dari adanya panatik terhadap satu pendapat Guru terdahulu.

Keempat, sosialisasi tentang konsep zakat hasil pertanian padi sangatlah minim dilakukan, hal ini disebabkan karena berbagai faktor, salah satunya adalah faktor sumber daya manusia yang masih rendah terutama dari segi kesadaran masyarakat untuk mengetahui bagaimana sesungguhnya pelaksanaan zakat padi itu yang sesuai dengan Al-Qur'an dan Sunnah Rasul. 


\section{PENUTUP}

Pelaksanaan zakat hasil petani padi dititik beratkan pada pemahaman.Yaitu petani dalam memahami hukum zakat, khususnya zakat pertanian padi memang sungguh sangat lemah. Sehingga pelaksanaan yang muncul dari ide mereka, berdasarkan kebiasaan orang- orang terdahulu.

Pelaksanaan zakat pertanian padi di Kec. Huristak Kab. Padang Lawas, ini banyak dipengaruhi oleh unsur masa lalu yang tidak jelas dari mana asal mausulnya. Dalam hal ini, kebiasaan masyarakat yang mengikuti aktifitas kebiasaan orang-orang terdahulu yang menyerahkan dan menerima zakat hasil pertanian padi itu. Ini berakar dari adanya panatik terhadap satu pendapat Guru terdahulu.

Alasan mustahiq mengembalikan hak zakatnya kepada muzakki setelah mengambilnya sebagian di Kec. Huristak Kab Padang Lawas. Dari masingmasing para petani padi yang sudah berkewajiban membayar zakat penghasilannya (cukup nisab). Mustahiq mengatakan zakat itu hak kita hanya 1/8 saja, sedangkan selebihnya adalah menjadi hak orang lain, oleh karena mustahiq tidak bisa memberikan kepada mustahiq yang sebagian lagi maka zakat dikembalikan kepada muzakki agar dapat diberikan kepada yang lain.

Sosialisasi tentang konsep zakat hasil pertanian padi sangatlah minim dilakukan, hal ini disebabkan karena berbagai faktor, salah satunya adalah faktor sumber daya manusia yang masih rendah terutama dari segi kesadaran masyarakat untuk mengetahui bagaimana sesungguhnya pelaksanaan zakat padi itu yang sesuai dengan Al-Qur'an dan Sunnah Rasul. 
362 | TAZKIR: Jurnal Penelitian Ilmu-ilmu Sosial dan Keislaman

Vol. 04 No. 2 Desember 2018

\section{DAFTAR BACAAN}

Agama RI, Departemen, Al-Qur'an dan Terjemahannya, Surabaya: Duta Ilmu. 2005.

Azwar, Syaifuddin, Metode Penelitian,Yogyakarta: Pustaka Pelajar, Cet 1, ed.1.1998.

Arikunto, Suharsini, Prosedur Penelitian Suatu Pendekatan Praktek, Cet. Ke-12, Jakarta: Rineka Cipta, 2002.

Abu Achmadi, Cholid Narbuko, Metodologi Penelitian, Jakarta: PT. Bumi Aksara, Cet. 5, 2003.

Adi, Rianto, Metodologi Penelitian Sosial dan Hukum, Jakarta: Granit, 2004.

Amin Summa, Muhammad., et. Al., Buku Pintar Panduan Praktis Zakat, Jakarta: Inti Mandiri Sejahtera, 2003.

Al-Qardhawi, Yusuf., Al- Ibadah Fi Al- Islam, Beirut: Muasasah Risalah, 1993.

Ash-Shiddieqy, T. M.Hasbi., Pedoman Zakat, Cet. 5, Jakarta: PT. Bulan bintang, 1984.

Ghozalai, M. Sukri., et. al., Pedoman Zakat 9 Seri, Jakarta: Gema Insani Press, Cet. Ke$1,2002$. Insani, 1998.

Mahmud Al-Ba'ly, Abdul Al-Hamid., Ekonomi Zakat: Sebuah Kajian moneterdan Keuangan Syari'ah, ed. 1, jakarta : PT Raja Grafindo Persada, 2006.

Nawawi dan Mimi kartini, Hadari., Penelitian Terapan, Yogyakarta, Gajah mada University Press, 1996.

Purnomo, Syaechul hadi, Sumber-sumber Penggalian zakat, Jakarta: Pustaka Firdaus, 1992.

Wawancara dengan bapak H. Rahmat Siregar, Pemuka Agama Kec Huristak Kab Padang Lawas, tgl. 8 Desember 2017, Jam 11.30 WIB.

Qhqrdqwi, Yusuf., Hukum Zakat : Studi Komperatif Mengenai status dan filsafat Zakat berdasarkan Qur'an hadits, diterjemahkan oleh Salman Harun, et.al. Bogor ; Pustaka Litera Antar nusa, 2002.

-----------., Hukum Zakat: Studi Komperati Mengenai Status dan Filsafat Zakat Berdasarkan qur'an hadits, Bogor : Pustaka Litera Antar Nusa, 2002.

---------------., Hukum zakat, Terjemahan: Salma Harun, Didin Hafidhuddin, Hasanuddin, bandung : Mizan, Cet ke-4, 1993. 